\title{
Convergence trends of environmental taxation in European countries
}

\author{
Alina Vysochyna ${ }^{1 *}$, Yaryna Samusevych ${ }^{1}$, and Liudmyla Starchenko ${ }^{2}$ \\ ${ }^{1}$ Sumy State University, Department of Accounting and Taxation, 40007 Sumy, Ukraine \\ ${ }^{2}$ Sumy State University, Department of Economics, Entrepreneurship and Business Administration, \\ 40007 Sumy, Ukraine
}

\begin{abstract}
The aim of the paper is to analyse peculiarities of building an environmental tax systems, examining the level of their convergent (divergent) relationships. Main contribution of the paper lies in testing of the hypothesis of existing convergence processes in architecture of environmental tax systems of European countries (as the United Kingdom, Germany, Poland, Slovenia, Latvia, Lithuania and the Czech Republic) on the basis of panel data analysis for the set of European countries using the regression model in Stata 12/SE and MS Excel. Testing the hypothesis about the existence of convergence in construction of environmental tax system of the above mentioned European countries was realized on the base of analysis of coefficients of panel data regression analysis (both fixed effects and random effects models) - for beta convergence and variation coefficient for sigma convergence. Such parameters as environmental tax revenue (for air pollution) to general tax revenues ratio, \%; environmental tax revenue (for water pollution) to general tax revenues ratio, \%; environmental tax revenue (for waste management) to general tax revenues ratio, \% were chosen as measures of environmental tax system characteristics. Empirical research results confirmed hypothesis of the presence of $\beta$-convergence and $\sigma$-convergence in the context environmental tax systems of chosen countries.
\end{abstract}

\section{Introduction}

The development of world economic relations over the last few decades has been accompanied by a radical transformation of business conditions. Thus, in particular, the strengthening of integration processes and liberalization of commodity and financial markets have led to emergence both positive changes (intensification of cross-border trade, supranational cooperation in the fight against global threats, rapid development of spheres and branches of national economy) and negative consequences (exacerbation of global problems, especially of environmental ones; increasing the scale and dynamics of crisis processes and their rapid transmission; increasing competition in various traditional and nontraditional sectors, etc.).

* Corresponding author: a.vysochyna@uabs.sumdu.edu.ua 
It is worth noting that one of the most threatening challenges facing the global community at the present stage of development is the mitigation of the effects of anthropogenic impact on the ecosystem, since the absence of deliberate and coordinated action in this direction can have irreversible and catastrophic effects in the immediate future. Thus, the solution of environmental problems at the supranational and national levels is possible with the use of instruments of state regulation of stimulating economy (implementation of diversified preferences for economic entities for the purpose of ensuring environmentally responsible behaviour) and restraining instruments (application of fiscal mechanisms to those economic agents, which have a destructive effect on the environment).

In general terms, the theory of economic convergence is to approximate the development of countries by certain criteria and to acquire common features. The essence of tax convergence is the alignment of indicators that reflect the conditions of taxation (tax rates, tax burden, structure of tax systems, etc.). It should be noted that at the present stage of development tax convergence processes are closely linked to the tax harmonization strategy, which is being implemented most rapidly in the countries of the European continent [1].

Convergence in the EU and in the Euro area is a necessity: the European growth strategy cannot be blind to sustained regional growth differences. An EU in which economic growth does not spread through all of its major regions will be politically challenged. The paradox is that many of the policy instruments to address this problem remain in the hands of national policymakers, even though the way they use them has significant implications for the rest of the EU. The EU supports convergence through its budget and technical support but the fundamentals of this paradox remain. In the Euro area, further measures are needed to address some of the systemic causes of divergence. In particular, it is imperative to complete banking union and for capital markets to become more integrated, since a well-functioning financial system is fundamental for growth. A Euro-area safe asset would bring benefits but is difficult to establish. EU fiscal rules need to be reformed to improve the macroeconomic management of the euro area. A euro-area budget and more responsive national fiscal policies are important tools to better respond to cyclical downturns [2]. Finally, the relationship between the Euro area and non-Euro area countries needs to be addressed.

Thus, the aim of the paper is to analyse peculiarities and the different countries' patterns of building an environmental tax system, examining the level of their convergent (divergent) relationships. Main contribution of the paper lies in testing of the hypothesis of existing convergence processes in architecture of environmental tax systems of European countries on the basis of panel data analysis for the set of European countries using the regression model in Stata 12/SE and MS Excel.

\section{Literature review}

Thus, in previous studies [3] it was analyzed how the implementation of the Millennium Development Goals affects environmental sustainability in Ukraine and abroad, but in September, 201517 global goals for sustainable development were adopted at the United Nations General Assembly (Sustainable Development Goals by 2030). These goals cover various projections, in particular, poverty reduction, quality education, struggling with gender discrimination, addressing a number of environmental problems.

Therefore, paying huge attention to the environmental problems both at national and supranational levels allows supporting the idea about dramatically importance of regulation of this sphere via institutional, social, economic and especially fiscal instruments. Formation of environmentally responsible behaviour at corporate and personal levels contributes to solving environmental problems. 
Thus, scientists [4-11] argued that institutional preconditions play crucial role in expansion of environmental responsibility at corporate and personal levels (household and business environmental performance is a result of regulatory requirements fulfilment).

While other group of scientists [12-22] highlighted that business involvement in environmental problems solving mostly dependent on microeconomic issues and market conditions (financial capacity of company, business brand, competition and cooperation circumstances, investment attractiveness, managerial priorities etc.).

In turn, some researchers [23-32] stand at a point that further expansion of environmental responsibility is triggered by primary environmental prerequisites (for instance, expansion of renewable electricity outputs leads to intensification of economic growth that in turn allows business to finance more environmental initiatives; or expansion of green investments helps to increase business performance and in turn realize more large-scale investment projects, etc.)

Moreover, other scientists [33-47] realize that environmental responsibility might be implemented only in more or less favourable socio-economic conditions (priority on environmental issues at national, regional and local levels becomes possible only after achieving basic targets of social and economic KPIs).

It should be noted that among the variety of economic instruments of environmental problems elimination fiscal instruments are the most effective ones. Namely, fiscal stimulus tools (tax incentives, etc.) and tax restraints (increasing rates and expanding the tax base of environmental taxes) can be used to solve these problems. An analysis of world experience has shown that, traditionally, the environmental tax system consists of such elements as energy taxes; taxes on greenhouse gas emissions; transport taxes; taxes on environmental pollution; resource taxes (for the use of natural resources).

There are some scientists [48-51] focused on researching the existence of convergent processes in the international tax environment. Namely, tax competition and convergence appear while reforming tax systems in order to attract taxpayers and investments to create additional working places and to stimulate economic growth [52].

Studies of the foreign capital taxation carried out in the 60 s of the twentieth century by Kemp [53] and MacDougall [54] enabled to find out about tax system efficiency increases in case of non-resident capital taxation by the location of the investor as opposed to tax collection on the principle of the income source. In that period, there were first attempts to define an optimal level of foreign capital income taxation. The regional tax competition theory, formalized by Zodrow and Mieszkowski [55], based on Tiebout's basic model of the tax competition, enabled to demonstrate the capital mobility impact on tax rates level, which are set on the capital income, expressed by the inverse dependence.

At the present time tax competition and convergence is an important factor to make investment decisions at the international level, which taking into account production integration and mobility factors level increase, determines entrepreneurship activity at the countries' level given the difference of national and abroad taxation terms. Nowadays tax factors are not only components, which provide the financial efficiency of companies, but also define corporate social and environmental responsibility tendencies [56].

It should be noted that there are lack of researches aimed at assessing convergence trends in taxation. In particular, the study of tax convergence in the countries of the European Union, conducted by Delgado [1] for the period 1965-2010, which included the calculation of the fiscal distance between indices of individual countries and the average for EU-15 level by indicators of total tax burden and burden by individual groups of taxes. The results of the calculations confirmed the convergence of the overall level of tax burden in the European Union. Sigma convergence estimation showed that the rate of convergence of the general level of taxation is $0.73 \%$ per year; the level of tax burden on income and profit $-0.46 \%$; tax burden on goods and services $-0.82 \%$; the social contributions burden is $0.73 \%$. The beta 
convergence assessment confirmed its existence for total tax burden, tax burden on income and profits, and goods and services (annual convergence rate is $2.06 \% ; 2.11 \% ; 2.94 \%$ respectively), whereas the results obtained for the level of social security contributions were not statistically significant. Taking into account the results obtained previously by the author, it might be noted that the countries of the European Union are characterized by a permanent convergence of the level and structure of tax revenues, which is most clearly observed in the period 1965-2003.

While there are some researches concerning convergent processes in taxation in general, but there is lack of it aimed at assessment of convergence in environmental taxation. Thus, it becomes an urgent task to focus on clarification of environmental tax convergence in European countries. It also becomes necessary to research this issue because of euro integration vector of Ukraine.

\section{Methodology}

In order to realize the above-mentioned task we tested the hypothesis about the existence of sigma convergence and beta convergence by using variation coefficient (1) and coefficient of panel data regression model (2). Technically, it was realized with Stata 12/SE and MS Excel.

The formula for estimating the level of sigma convergence using the coefficient of variation is as follows:

$$
C V_{t}=\frac{\left(\frac{1}{n} \sum_{i=1}^{n}\left(y_{i t}-\overline{y_{t}}\right)^{2}\right)^{1 / 2}}{\bar{y}_{t}}
$$

where $\bar{y}_{t}$ - average level of the indicator,

$y_{i t}-$ level of the indicator in i country, $\mathrm{i}=\overline{1, n}$

It should be noted that the value of the coefficient of variation of less than $33 \%$ confirms the thesis of sampling homogeneity and, accordingly, the presence of convergent processes.

In turn, $\beta$-convergence reflects the dynamics of fiscal gaps in selected indicators of the development of tax systems in the world. A classic one beta convergence estimation technique developed by R. Barro and X. Sala-i-Martin [57] based on the Solow model. According to this approach, the presence of convergence illustrates the negative value of the regression coefficient constructed by the formula:

$$
\ln \left(\frac{y_{i, t+1}}{y_{i, t}}\right)=\alpha+\beta \ln \left(y_{i, t}\right)+\varepsilon_{\mathrm{i}, \mathrm{t}}
$$

where $y_{i, t}-$ level of the indicator in i country $(i=\overline{1, n})$ in basic period $(t=\overline{1, T-1})$;

$y_{i, t+1}-$ level of the indicator in i country $(i=\overline{1, n})$ in current period $(t=\overline{2, T})$;

$\beta$ - coefficient that illustrates $\beta$-convergence (if $\beta<0$ );

$\varepsilon_{\mathrm{i}, \mathrm{t}}$ - error term. 
However, it is fair to point out that despite the existence of some expertise by scientists on the formalization of convergent relationships in terms of the overall level of tax burden, consumption, labour and capital taxes, the environmental taxation segment is underresearched. In this regard, it is proposed to analyse the existence of beta and sigma convergence in selected European countries by individual groups of environmental tax indicators. Research is based on data collected for 7 European countries such as the United Kingdom, Germany, Poland, Slovenia, Latvia, Lithuania and the Czech Republic. Time horizon of the research is 2004-2017. All data collected from the Eurostat [58].

The set of variables estimated in the research consists of:

- environmental tax revenue (for air pollution) to general tax revenues ratio, $\%$;

- environmental tax revenue (for water pollution) to general tax revenues ratio, $\%$;

- environmental tax revenue (for waste management) to general tax revenues ratio, $\%$.

Research consists of a few stages: 1) testing the hypothesis on existence of sigma convergence between countries; 2) testing the hypothesis on existence of beta convergence using both random effects and fixed effects models (takes into account influence of country specific features on variation of dependent variable). The first stages of the research was realized with the MS Excel tool and the second - with panel data regression analysis of Stata $12 / \mathrm{SE}$.

\section{Results}

General information on the set of variables for the chosen European countries over the period 2004-2017 is presented in table 1 .

Table 1. Descriptive statistics for the set of variables.

\begin{tabular}{|l|c|c|c|c|c|}
\hline Variable & Obs & Mean & Std.Dev. & Min & Max \\
\hline X1 & 105 & 7.52 & 1.703 & 4.46 & 12.02 \\
\hline X2 & 105 & 7.574 & 1.636 & 4.46 & 12.02 \\
\hline X3 & 105 & 7.612 & 1.541 & 5.28 & 12.02 \\
\hline
\end{tabular}

Note: X1 - environmental tax revenue (for air pollution) to general tax revenues ratio, \%; X2 environmental tax revenue (for water pollution) to general tax revenues ratio, \%; X3 - environmental tax revenue (for waste management) to general tax revenues ratio, $\%$.

Therefore, the results of testing the hypothesis of the existence of sigma convergence among selected European countries are presented in Figure 1. 


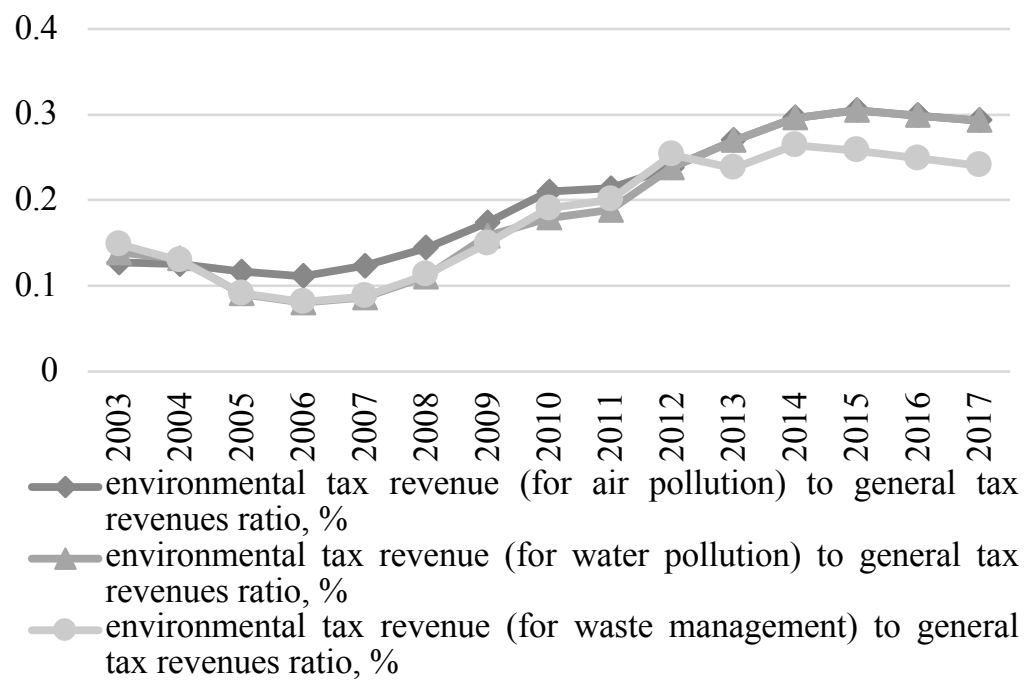

Fig. 1. Results of evaluation of $\sigma$-convergence process in environmental taxation systems in European countries in 2004-2017.

According to Figure 1, we can conclude that the $\sigma$-convergence exists in the environmental tax systems of selected European countries, but after a rather intensive process of harmonization of environmental tax trends during 2003-2008, the tendency to increase of the variation of the analyzed parameters is activated in the post-crisis period, especially in terms of environmental taxes, regulating air and water pollution, while in terms of taxes for waste management it is observed somewhat lower level of intensive of divergent processes in the period 2012-2017.

The results of the practical testing of beta convergence are presented in Table 2 .

The results presented in the table testify to the existence of $\beta$ - convergence over all three vectors of the environmental tax system, which is confirmed by statistically significant negative coefficients of the fixed effects regression models (at $99 \%$ confidence interval). 
Table 2. Results of evaluation of $\beta$ - convergence processes in the environmental tax systems of European countries in 2004-2017.

\begin{tabular}{|c|c|c|c|c|}
\hline $\begin{array}{c}\text { Indicator of tax } \\
\text { system } \\
\text { development }\end{array}$ & $\begin{array}{c}\text { Coeffici } \\
\text { ent }\end{array}$ & $\begin{array}{c}\text { Standar } \\
\text { d error }\end{array}$ & $\mathrm{p}>|\mathrm{t}|$ & $\begin{array}{c}\text { Prob }> \\
\text { chi2 }\end{array}$ \\
\hline \multicolumn{5}{|c|}{$\begin{array}{c}\text { Environmental tax revenue (for air pollution) to general tax } \\
\text { revenues ratio. \% }\end{array}$} \\
\hline $\begin{array}{c}\text { Model with } \\
\text { random effects }\end{array}$ & 0.003 & 0.032 & 0.915 & 0.9146 \\
\hline $\begin{array}{c}\text { Fixed effects } \\
\text { model }\end{array}$ & -0.224 & 0.056 & 0.000 & 0.0001 \\
\hline $\begin{array}{c}\text { Environmental tax revenue (for water pollution) to general tax } \\
\text { revenues ratio. \% }\end{array}$ & 0.036 & 0.939 & 0.9385 \\
\hline $\begin{array}{c}\text { Model with } \\
\text { random effects }\end{array}$ & -0.003 & 0.056 & 0.002 & 0.0019 \\
\hline $\begin{array}{c}\text { Fixed effects } \\
\text { model }\end{array}$ & -0.179 & 0.042 & 0.204 & 02044 \\
\hline $\begin{array}{c}\text { Environmental tax revenue (for waste management) to general } \\
\text { tax revenues ratio. \% }\end{array}$ & 0.0000 \\
\hline $\begin{array}{c}\text { Model with } \\
\text { random effects }\end{array}$ & -0.053 & 0.042 & 0.000 & 0.0000 \\
\hline $\begin{array}{c}\text { Fixed effects } \\
\text { model }\end{array}$ & -0.291 & 0.064 & 0
\end{tabular}

At the same time, the significance of the results using only the specification of the model with fixed, not random effects allows to state the need to take into account the specific economic and social development of a particular country in the context of convergence of qualitative characteristics of environmental taxation systems, i.e. despite the presence of strong convergent relationships, harmonization of the construction of environmental tax systems in the selected countries needed to be significantly personalized.

\section{Conclusions}

The formation of environmentally responsible behaviour at corporate and personal levels contributes to solving environmental problems. In general, to solve the problems there can be used as a stimulant fiscal instruments (tax benefits etc.) as well as constraints tax mechanisms (increase in rates and broadening the tax base of environmental taxes). Analysis of world experience has shown that traditionally, the environmental tax system includes such elements as energy taxes; taxes on greenhouse gas emission; transport taxes; taxes on environmental pollution; resource taxes (for the use of natural resources). Comparison of the architecture of the environmental tax system in Ukraine and 7 European countries showed the need for further harmonization in this area (especially with regard to the increase of individual tax rates), but at the same time revealed a lack of fiscal stimulus mechanisms in Ukraine (promising is the implementation of tax holidays for environmental taxpayers taxes, temporary exemption from taxation of certain transactions, exclusion from the taxation of certain objects, etc.).

According to the results of testing the hypothesis of the presence of $\beta$-convergence and $\sigma$-convergence in the context of the parameters of the characteristics of environmental tax systems (environmental tax revenue (for air pollution) to general tax revenues ratio, \%; environmental tax revenue (for water pollution) to general tax revenues ratio, \%; 
environmental tax revenue (for waste management) to general tax revenues ratio, \%) of European countries (United Kingdom, Germany, Poland, Slovenia, Latvia, Lithuania and the Czech Republic ), the presence of both types of convergence was generally confirmed in 2004-2017. However, in the context of the characterization of the $\sigma$-convergence level, some activation of divergent processes can be noted since 2008, whereas the presence of the $\beta$ convergence phenomenon is confirmed throughout the time horizon of the analysis using a fixed effects regression model. Thus, it can be noted that, despite strong convergence, the harmonization of environmental taxation systems in European countries should be significantly personalized.

The survey was supported by the Ministry of Education and Science of Ukraine and performed the results of the project "Structural-functional multiplex model of ecological tax system building in Ukraine in the context of national security" (registration number 0119U100759).

\section{References}

1. F. J. Delgado. JGE 1(1), 24-26 (2013).

2. Convergence Reports (2020) // European Commission. Retrieved 01.03.2020 from https://ec.europa.eu/info/business-economy-euro/euro-area/enlargement-euroarea/convergence-reports_en.

3. A. Vysochyna, I. Samusevych, V. Tykhenko, APE 171(9), 263-269 (2015). http://nbuv.gov.ua/UJRN/ape_2015_9_35

4. H. Dkhili, MMI 3, 333-244 (2018). http://doi.org/10.21272/mmi.2018.3-30

5. V. Koziuk, Y. Hayda, O. Dluhopolskyi, Y. Klapkiv, E\&S 12(4), 278-298 (2019)

6. Y. Bilan, A.G. Raišienė, T. Vasilyeva, O. Lyulyov, T. Pimonenko, PPA 18(2), 241-255 (2019)

7. Y. Bilan, T. Vasilyeva, S. Lyeonov, K. Bagmet, Bus.: Th\&Pr 20, 103-115 (2019). DOI: https://doi.org/10.3846/btp.2019.10.

8. I. Makarenko, N. Sirkovska, BEL 1(1), 16-24 (2017)

9. V. Sukhonos, I. Makarenko, PPM 15(1), 166-174 (2017)

10. O. Lyulyov, T. Pimonenko, N. Stoyanets, N. Letunovska, Res. WE 10(4), 97-105 (2019)

11. T. Vasilyeva, S. Bilan, K. Bagmet, R. Seliga, E\&S 13(1), 271-294 (2020)

12. T. Pimonenko, Y. Bilan, J. Horák, L. Starchenko, W. Gajda, Sustainability (Switzerland), 12(4), 1679 (2020). https://doi.org/10.3390/su12041679.

13. Y. Bilan, S. Lyeonov, O. Lyulyov, T. Pimonenko, Pol. J. Man. St., 19(2), 61-74 (2019)

14. S. Lyeonov, T. Pimonenko, Y. Bilan, D. Štreimikiene, G. Mentel, Energies 12(20), 3891 (2019)

15. H. Shvindina, Saf., 5(3), 61 (2019).

16. L.L. Hrytsenko, T.Y. Krasulya, APE 126(12), 85-90 (2011).

17. M. Bublyk, V. Koval, O. Redkva, MMI (4), 229-240 (2018). https://doi.org/10.21272/mmi.2017.4-20.

18. A. Masharsky, G. Azarenkova, K. Oryekhova, S. Yavorsky, MMI arketing and Management of Innovations, 3, 345-354 (2018). http://doi.org/10.21272/mmi.2018.331.

19. I. Pomianek, BEL 2(2), 74-83 (2018). DOI: 10.21272/bel.2(2).74-83.2018.

20. Y. Bilan, P. Rubanov, T. Vasylieva, S. Lyeonov, Pol. J. Man. St. 9(1), 70-93 (2019) 
21. Y. Bilan, O. Kuzmenko, A. Boiko Research on the impact of industry 4.0 on entrepreneurship in various countries worldwide, in Proceedings of the 33rd International Business Information Management Association Conference, IBIMA 2019: Education Excellence and Innovation Management through Vision 2020, 2373 2384 (2019). https://ibima.org/accepted-paper/research-on-the-impact-of-industry-4-0on-entrepreneurship-in-various-countries-worldwide/

22. Y. Bilan, T. Pimonenko, L. Starchenko, E3S Web of Conferences 159, 04037 (2020)

23. Y. Bilan, S. Lyeonov, N. Stoyanets, A. Vysochyna. IJETM, 21(5-6), 289-305 (2018)

24. O. Lyulyov, T. Vasylieva, ESD 1, 878-887 (2019)

25. G. Mentel, T. Vasilyeva, Y. Samusevych, S. Pryymenko, IJETM 21(5-6), 354-372 (2018)

26. T. Vasilyeva, O. Kuzmenko, V. Bozhenko, O. Kolotilina, Assessment of the dynamics of bifurcation transformations in the economy, in CEUR Workshop Proceedings, 2422, 134-146 (2019).

27. H. Zhang, E. Xu, Sc. Rep., 7, 811, (2017). DOI: 10.1038/s41598-017-00899-x.

28. I. Aliyas, E. Ismail, M. Alhadeedy, SEC 2(2), 75-80 (2018)

29. O. Chygryn, T. Pimonenko, O. Luylyov, A. Goncharova, J. Env. Man. and T. 9(7), 1443-1456 (2018)

30. J. Cebula, O. Chygryn, S.V. Chayen, T. Pimonenko, IJETM 21(5-6), 421-438 (2018)

31. Y. Yevdokimov, O. Chygryn, T. Pimonenko, O. Lyulyov, Inn. Mark. 14(2), 7-15 (2018)

32. O.V. Kozmenko, O.M. Pakhnenko, APE 118(4), 217-223 (2011).

33. Y. Matvieieva, I. Myroshnychenko, L. Valenkevych, JEMT 10(8), 1874-1899 (2019)

34. Y. Bilan, M. Brychko, A. Buriak, T. Vasilyeva, ZREFR 37(1), 113-138 (2019)

35. L.F. Sokolenko, I.V. Tiutiunyk, D.V. Leus, IJED 32(3), 27-35 (2017).

https://www.academia.edu/40570162/Ecological_and_Economic_Security_Assessment in_the_System_of_Regional_Environmental_Management_A_Case_Study_of_Ukrai ne.

36. A. Stavytskyy, G. Kharlamova, V. Giedraitis, V. Šumskis, JIS 11(3), 217-238 (2018)

37. I.V. Tiutiunyk, IJED 33 (3), 11-18 (2018). https://essuir.sumdu.edu.ua/bitstreamdownload/123456789/74030/1/P2-Determination.pdf.

38. I. Kendiukhov, M. Tvaronavičienè, MMI 3, 33-42 (2017). DOI: http://doi.org/10.21272/mmi.2017.3-03.

39. S.N. Singh, SEC 2(2), 41-48 (2018)

40. D.T.Am. Marcel, FMIR 3(2), 69-78 (2019). DOI: http://doi.org/10.21272/fmir.3(2).6978.2019.

41. H. Dave, BEL 1(2), 78-87 (2017)

42. H. Dave, BEL 1(3), 45-63 (2017)

43. T. Bondar, Y. Matvieieva, I. Myroshnychenko, Ec. An.-XXI 7-8(1), 40-44 (2015). http://soskin.info/userfiles/file/2015/7-8_1/Bondar_Matvieieva_Myroshnychenko.pdf.

44. Y. Bilan, T. Vasylieva, S. Lyeonov, I. Tiutiunyk, EBER 7(2), 27-43 (2019)

45. A. Grenčíková, Y. Bilan, Y. Samusevych, A. Vysochyna, Drivers and inhibitors of entrepreneurship development in central and eastern European countries, in Proceedings of the 33rd International Business Information Management Association Conference, IBIMA 2019: Education Excellence and Innovation Management through 
Vision 2020, 2536-2547 (2019). https://ibima.org/accepted-paper/drivers-andinhibitors-of-entrepreneurship-development-in-central-and-eastern-european-countries/

46. T. A. Vasylyeva, S. A. Pryymenko, APE 160(1), 252-260 (2014).

https://www.researchgate.net/publication/297884624_Environmental_economic_assess ment_of_energy_resources_in_the_context_of_ukraine's_energy_security

47. T. Vasilyeva, S. Lyeonov, I. Adamičková, K. Bagmet, E\&S 11(2), 248-262 (2018)

48. Y. Bilan, S. Lyeonov, T. Vasylieva, Y. Samusevych, Online J. Model.New Eur. (27), 34-66 (2018)

49. L. Rui, L. Sineviciene, L. Melnyk, (...), O. Karintseva, O. Lyulyov, PPM 17(3), 233241 (2019)

50. A. Boiko, I. Samusevych, FMIR 1(1), $72-79$ (2017). http://doi.org/10.21272/fmir.1(1).72-79.2017.

51. Y. Bilan, T. Vasilyeva, O. Lyulyov, T. Pimonenko, IJBS 20(2), 433-450 (2019). http://www.ijbs.unimas.my/images/repository/pdf/Vol20-no2-paper1.pdf

52. T. Field, STN 98 (14), 1211-1216 (2003).

53. M. Kemp, Econ. Rec. 28, 56-62 (1961).

54. G. MacDougall, Econ. Rec. 36, 13-35 (1960).

55. G. Zodrow, P. Mieszkowski, JUE 19, 356-370 (1986).

56. C. M. Crișan, D. C. Dabija, V.Dinu, MJE 11 (2), 65-77 (2015).

57. R. J. .Barro, X. Sala-i-Martin (2003) Economic growth. 2nd ed. London: The MIT Press, 673.

58. Environmental tax revenues (2020) // Eurostat. Retrieved 01.03.2020 from http://appsso.eurostat.ec.europa.eu/nui/show.do?dataset=env_ac_tax\&lang=en. 